\title{
Florid skin rash in acute myeloid leukaemia
}

\author{
Nischala Ammannagari, ${ }^{1}$ Quanhathai Kaewpoowat, ${ }^{1}$ Supawat Ratanapo, ${ }^{1}$ \\ Anush Patel $^{2}$
}

${ }^{1}$ Department of Internal Medicine, Bassett Medical Center, Cooperstown, New York, USA

2Department of Hematology/ Oncology, Bassett Medical Center, Cooperstown, New York, USA

\section{Correspondence to} Dr Nischala Ammannagari, nischala.ammannagari@ bassett.org
To cite: Ammannagari $\mathrm{N}$, Kaewpoowat Q, Ratanapo $\mathrm{S}$, et al. BMJ Case Rep Published online: [please include Day Month Year] doi:10.1136/bcr-2012 008159

\section{DESCRIPTION}

A 64-year-old gentleman was diagnosed with acute myeloid leukaemia (AML) 3 years ago and was treated with cytarabine and daunorubicin induction chemotherapy followed by three cycles of highdose cytarabine consolidation treatment. Patient tolerated treatment extremely well and went into remission. About 4 months ago, he developed relapse of AML. He was admitted to our inpatient oncology service to begin high-dose cytosine arabinoside chemotherapy in anticipation of allogenic bone marrow transplant. ${ }^{1}$

On day 3 of chemotherapy, patient started developing new maculopapular, erythematous and pruritic skin eruption over his body. It initially began over his face and anterior chest and within $24 \mathrm{~h}$ it spread diffusely involving the entire body (figures 1 and 2). Initial impression was neutrophilic eccrine hidradenitis, which is a dermatosis primarily affecting the eccrine glands and occurs in patients undergoing chemotherapy with cytarabine. ${ }^{2}$ Skin biopsy was performed for diagnosis which revealed perivascular and interface dermatitis with purpura favouring drug eruption (figure 3). Antihistaminics were used as needed for patient's symptoms. The rash progressively worsened for 3 days and then started to resolve spontaneously. Patient did receive cytarabine again without any complications.

Cytarabine is an antimetabolite which is used in the treatment of AML. It has been associated with florid cutaneous reactions. ${ }^{3}{ }^{4}$ These reactions have been found to be dose related. ${ }^{3}{ }^{4}$ Most of

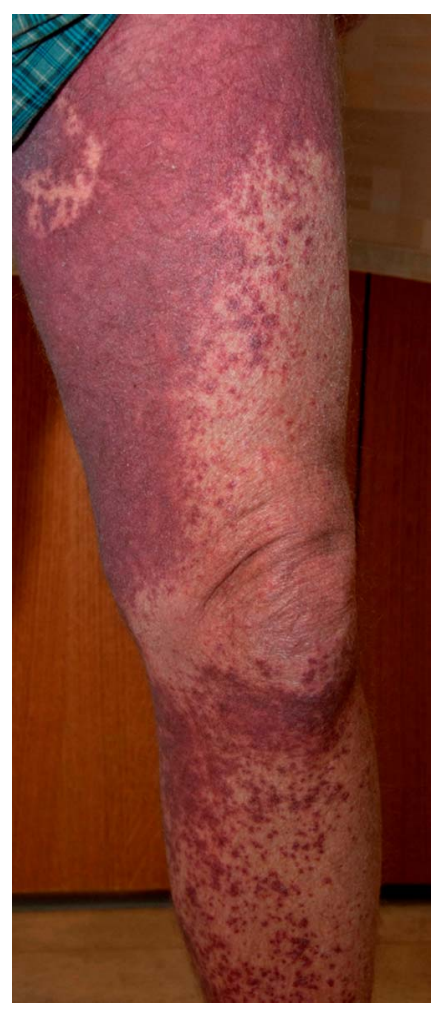

Figure 2 Rash involving the lower extremities.

them have spontaneous resolution. ${ }^{3}{ }^{4}$ Exact cause remains unknown though hypersensitivity reaction is strongly implicated and proinflammatory
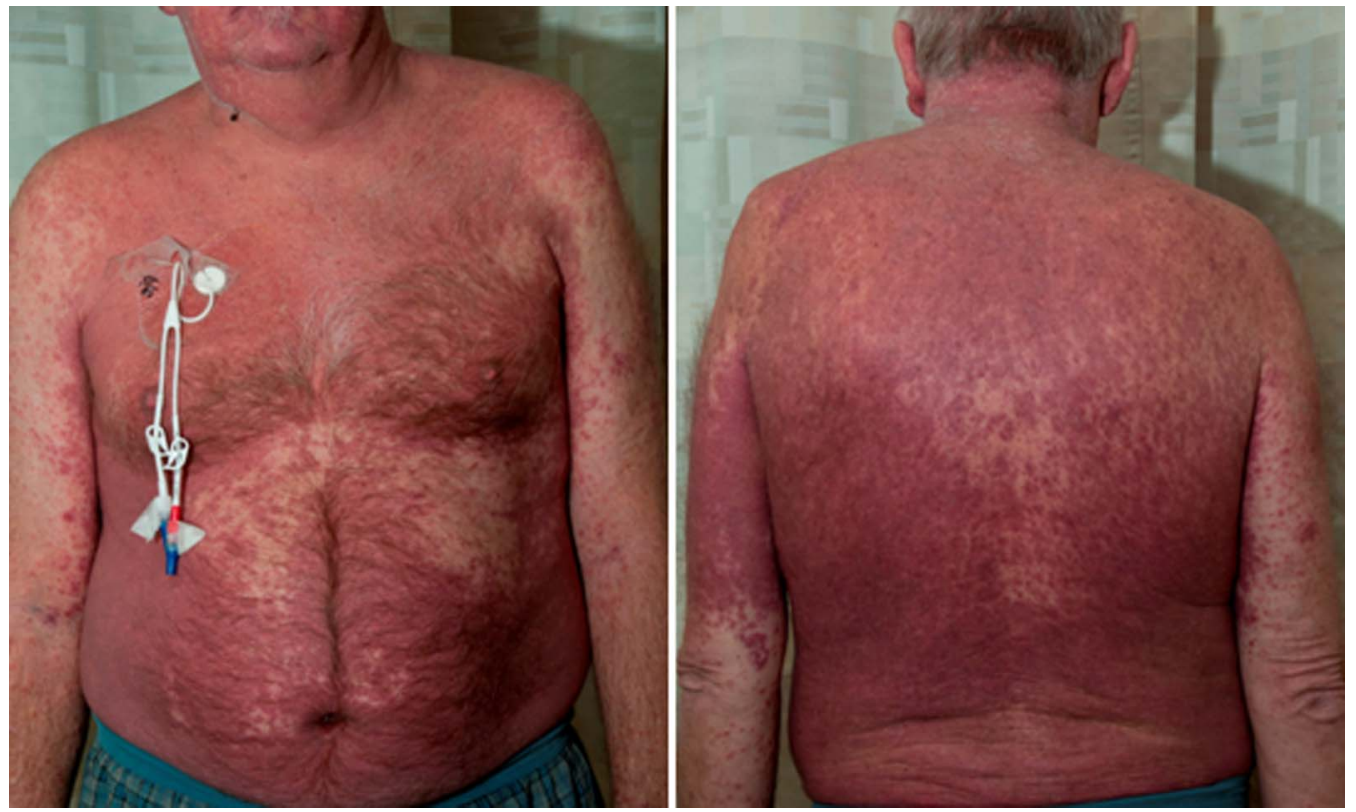

Figure 1 Maculopapular erythematous rash all over the trunk. 


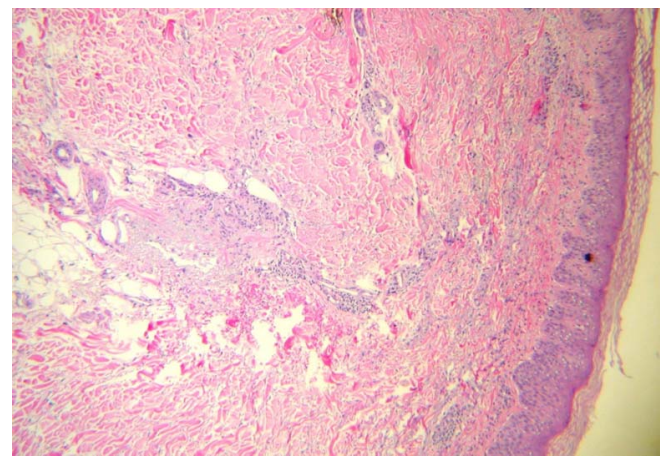

Competing interests None.

Patient consent Obtained.

Provenance and peer review Not commissioned; externally peer reviewed.

\section{REFERENCES}

1 Herzig RH, Wolff SN, Lazarus HM, et al. High-dose cytosine arabinoside therapy for refractory leukemia. Blood 1983;62:361-9.

2 Kanzaki $\mathrm{H}$, Oono T, Makino $\mathrm{E}$, et al. Neutrophilic eccrine hidradenitis: report of two cases. J Dermatol 1995;22:137-42.

3 Cetkovská P, Pizinger K, Cetkovský P. High-dose cytosine arabinoside-induced cutaneous reactions. J Eur Acad Dermatol Venereol 2002;16:481-5.

4 Tay J. Erythematous eruption in a man with acute myeloid leukemia. CMAJ 2002;167:672-3.

Figure 3 H\&E stain from skin biopsy showing diffuse dermatitis with purpura.

cytokines like IL-1, IL-6, Interferon- $\alpha$, tumour necrosis factor- $\alpha$ have been isolated. ${ }^{4}$

\section{Learning points}

- Cytarabine is associated with florid cutaneous reactions.

- These reactions are dose related.

- Though exact cause is unknown, hypersensitivity reactions are implicated.

Copyright 2013 BMJ Publishing Group. All rights reserved. For permission to reuse any of this content visit http://group.bmj.com/group/rights-licensing/permissions.

BMJ Case Report Fellows may re-use this article for personal use and teaching without any further permission.

Become a Fellow of BMJ Case Reports today and you can:

- Submit as many cases as you like

- Enjoy fast sympathetic peer review and rapid publication of accepted articles

- Access all the published articles

- Re-use any of the published material for personal use and teaching without further permission

For information on Institutional Fellowships contact consortiasales@bmjgroup.com

Visit casereports.bmj.com for more articles like this and to become a Fellow 